DOI: https://doi.org/10.24144/2409-6857.2018.2(52).166-170

УДК 336.71

Заславська О.I.

\title{
ІННОВАЦІЙНЕ ЗАБЕЗПЕЧЕННЯ ЕФЕКТИВНОСТІ ДЕПОЗИТНОЇ ПОЛІТИКИ БАНКУ
}

\begin{abstract}
У статті розглянуто проблеми впровадження банківських інновацій як фактора забезпечення ефективності депозитної політики банку. Визначено основні питання формування інновачійної стратегії та маркетингової політики банків. Здійснено аналіз депозитного портфеля ПАТ «Державний ощадний банк Украӥни», акцентовано увагу на питаннях впровадження інновацій у діяльність банку. Визначено шляхи удосконалення депозитної політики вітчизняних банків щодо цільових ринків та клієнтів, обсягів $i$ структури депозитної бази, форм та пріоритетів депозитної діяльності.
\end{abstract}

Ключові слова: депозитна політика, інноваційна стратегія, маркетинг депозитних послуг, інформаційні технологї, банківські інноваџї, онлайн-банкінг, Інтернет-банкінг, мобільний банкінг.

Постановка проблеми. Сталий розвиток банківської системи та ефективне функціонування банків у сучасному бізнес-середовищі визначаються ефективною політикою управління, ключовим об'єктом якої є банківські ресурси. Практика ринкових країн свідчить, що важливою умовою забезпечення стабільності та прибутковості банківського сектору $є$ обгрунтована конкурентоспроможна депозитна політика банків. У цьому аспекті важливим стратегічним напрямом розвитку ринку депозитних послуг в Україні $\epsilon$ інноваційна продуктова політика банківських установ, яка полягає у постійному оновленні асортименту продуктів і послуг та застосовуванні сучасних інформаційних технологій обслуговування клієнтів. Впровадження інновацій у діяльність банківської системи дозволяє підвищити якість банківських послуг, що у свою чергу забезпечує зростання дохідності та фінансової стійкості банків.

Аналіз останніх досліджень і публікацій. Про актуальність дослідження проблем формування депозитної бази банків i ролі інноваційної стратегії у забезпеченні ефективної реалізації депозитної політики свідчать численні праці зарубіжних і вітчизняних вчених, серед яких: Г. Айленбергер, А. Ашурбекова, Л. Бондаренко, Т. Васильєва, О. Васюренко, А. Вожжов, Ж. Довгань, Е. Дж. Долан, Р. Еллер, С. Сгоричева, О. Зайцев, Ю. Котелевська, Т. Кох, С. Князь, М. Марич, А. Маршалл, І. Мельникова, Т. Новікова, В. Ониськів, П. Роуз, Дж. Сінкі, Ж. Торяник, І. Федосік, Н. Чиж та інші.

(C) Заславська Ольга Ігорівна, к.е.н., доцент кафедри фінансів і банківської справи, ДВНЗ «Ужгородський національний університет», м. Ужгород, тел.: +380501011695, e-mail: olga.zaslavska@uzhnu.edu.ua
Істотне підвищення ролі депозитної політики банків у забезпеченні ліквідності та фінансової стійкості банківської системи України зумовлює необхідність подальших досліджень щодо удосконалення інноваційної стратегії вітчизняних банківських установ на депозитному ринку.

Формулювання цілей статті. Метою дослідження $\epsilon$ обгрунтування теоретичних $\mathrm{i}$ практичних аспектів формування та ефективної реалізації інноваційної стратегії та маркетингової політики вітчизняних банків на ринку депозитних послуг.

Опис основного матеріалу дослідження. У сучасних умовах банківський бізнес характеризується стрімким розвитком інформаційних і телекомунікаційних технологій, впровадженням дистанційного обслуговування клієнтів та розробкою інноваційної продуктової лінійки. Необхідною умовою підвищення конкурентоспроможності та зростання іміджу банку є наявність інноваційної стратегії розвитку, яка задає напрям для депозитної політики, формує структуру портфеля інноваційних продуктів та послуг. Створення ефективної стратегії розвитку передбачає врахування зовнішніх і внутрішніх факторів впливу.

Зовнішні фактори впливу включають:

- стан та перспективи розвитку економіки;

- глобалізаційні процеси у фінансовокредитній сфері;

- розвиток інформаційно-комунікаційних технологій та інновацій в економіці;

- кон'юнктуру ринку фінансових послуг;

- розвиток інноваційних процесів у банківській сфері тощо.

До внутрішніх чинників, які мають вплив на формування інноваційної стратегії банку, можна віднести такі: 
- рівень стабільності та фінансової стійкості банку;

— рівень інноваційного потенціалу банку;

- наявність дієвої системи ризик-менеджменту;

- стан інноваційної культури працівників банку тощо [2].

Дослідження вітчизняного депозитного ринку показали, що традиційні інструменти політики просування банківських продуктів, такі як реклама, робота 3 громадськістю та стимулювання попиту, вже не $\epsilon$ достатньо ефективними. Сьогодні вимогою часу $\epsilon$ використання нових маркетингових інструментів інноваційного забезпечення депозитної політики. Втім, варто зазначити, що, на думку експертів, попит на інноваційні банківські послуги в Україні ще не досягли достатнього рівня. Вітчизняний клієнт наразі не сприймає банк як фінансового радника і консультанта, тому банки здебільшого зосереджені на створенні нових продуктів. Серед інновацій маркетингу, які сьогодні $\epsilon$ альтернативою традиційним методам, виділяють неформальні канали комунікації, мобільні додатки, геймеризацію, використання інформаційних можливостей відомих компаній (Google, Facebook тощо). Відмінною рисою банківських інновацій у вітчизняних банках $є$ те, що вони, як правило, пропонуються корпоративними клієнтами. Так, серед діючих банківських інноваційних послуг $60 \%$ їхнього обсягу запропоновано клієнтами банку. При цьому основна увага приділяється не новизні продукту, а його унікальності та привабливості для клієнта [1].

У процесі дослідження видалося логічним проаналізувати депозитну політику та інноваційну стратегію впровадження сучасних банківських продуктів на прикладі конкретного вітчизняного банку, а саме ПАТ «Державний ощадний банк України». У банку розроблена i успішно реалізується стратегія «Мій банк. Моя країна», яка передбачає його трансформацію у два етапи:

- 2015-2017 роки - етап «Модернізація»;

- 2018-2020 роки - етап «Лідерство».

Стратегічними цілями Ощадбанку визначено такі: банк держави для держави; банк мільйонів для мільйонів; банк №1 серед системних банків [3].

Зважаючи на ситуацію, яка склалася у соціально-економічній сфері економіки України, основним завданням стратегії державних банків $\epsilon$ відновлення довіри населення та господарюючих суб'єктів до банківської системи. Саме на такий результат націлена депозитна політика ПАТ «Ощадбанк» протягом останніх п’яти років (рис. 1).

Дані, наведені на рис.1, свідчать, що впродовж

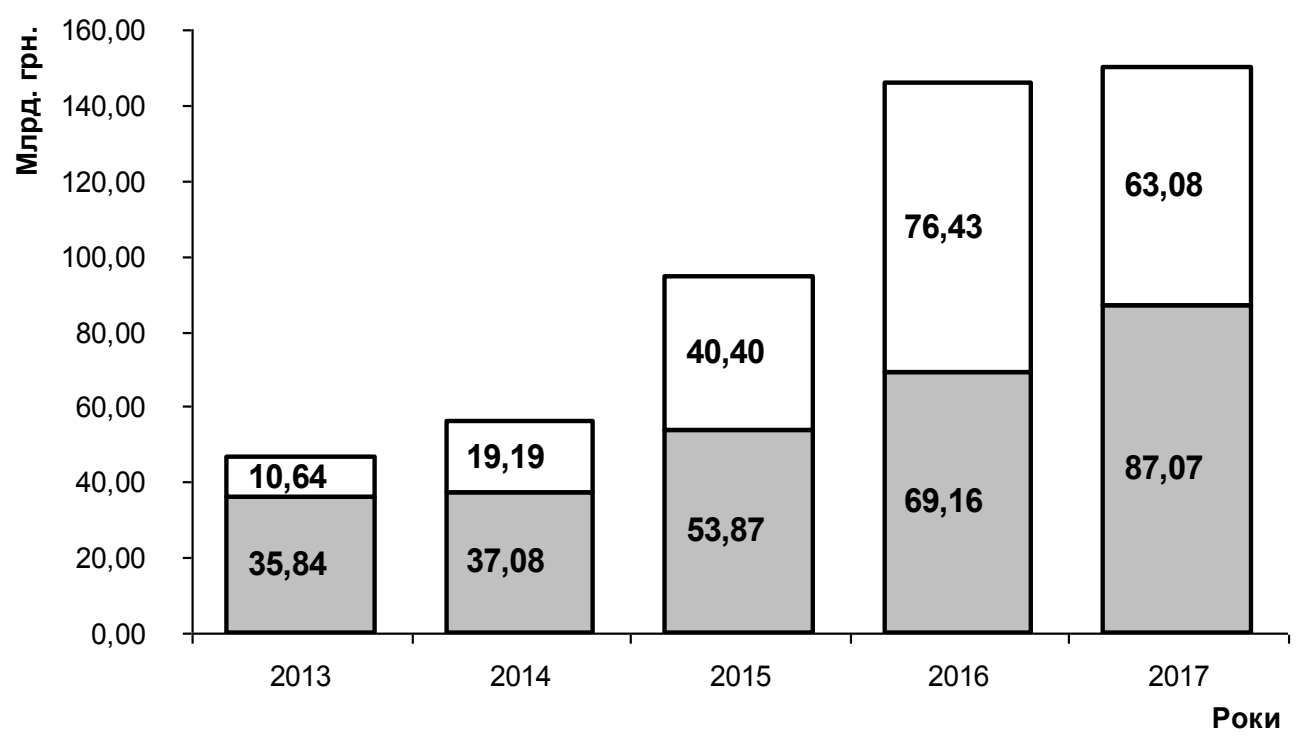

口 Депозити фрізичних осіб 口Депозити юридичних осіб

\section{Рис. 1. Динаміка депозитного портфеля ПАТ «Ощадбанк» у 2013-2017 рр. (на кінець періоду)* *Джерело: побудовано на основі [3]}

2013-2017 років депозитний портфель ПАТ «Ощадбанк» характеризувався стійкою тенденцією до зростання - 3 46,48 млрд. грн. у
2013 р. до 150,15 млрд. грн. у 2017 р. Щодо структури депозитного портфеля, необхідно звернути увагу на зменшення частки депозитів 
фізичних осіб із 77,1 \% у 2013 р. до 58,0 \% у 2017 p., тобто на $19,1 \%$. При цьому частка депозитів юридичних осіб зросла із 22,9 \% у 2013 р. до 42,0 \% на кінець 2017 р. (на 19,1 \%) [3]. Таку ситуацію можна пояснити недовірою населення до банківської системи, яка в останні роки характеризується нестабільністю та періодичними кризовими явищами. Окрім того, зберігається тенденція до зниження рівня заощаджень фізичних осіб внаслідок ускладнення політичної та соціально-економічної ситуації в країні. Втім, варто зазначити, що якщо у 2014 році спостерігалися щоденні відтоки 3 депозитних рахунків банку у розмірі 200-300 млн. грн., то за результатами 2016-2017 років Ощадбанк посів перше місце за приростом строкових депозитів фізичних осіб. Протягом цього періоду строкова ресурсна база банку збільшилась на 32,59 млрд. грн., із яких 18,72 млрд. грн. склали строкові кошти фізичних осіб. На кінець 2017 року обсяг строкових депозитів становив 82,04 млрд. грн., що на 13,93 млрд. грн. більше обсягу депозитів на вимогу (табл. 1).

У сучасних умовах найбільш актуальними

Таблиця 1

Депозити кліснтів ПАТ «Ощадбанк» у розрізі строковості у 2013-2017 рр. (на кінець періоду)*

\begin{tabular}{|c|c|c|c|c|c|c|c|c|c|c|}
\hline \multirow[b]{3}{*}{ Показник } & \multirow{2}{*}{\multicolumn{2}{|c|}{2013}} & \multirow{2}{*}{\multicolumn{2}{|c|}{2014}} & \multirow{2}{*}{\multicolumn{2}{|c|}{2015}} & \multirow{2}{*}{\multicolumn{2}{|c|}{2016}} & & \\
\hline & & & & & & & & & \multicolumn{2}{|c|}{2017} \\
\hline & 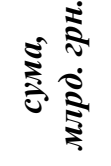 & 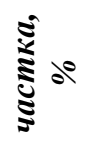 & 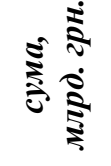 & 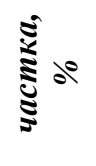 & 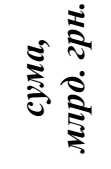 & 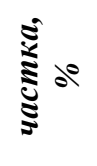 & 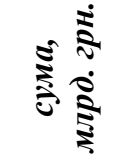 & 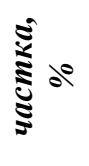 & 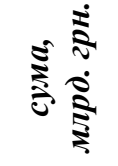 & 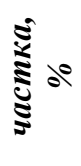 \\
\hline $\begin{array}{l}\text { Депозити } \\
\text { на вимогу }\end{array}$ & 17,84 & 38,4 & 21,69 & 38,5 & 44,82 & 47,5 & 77,86 & 53,5 & 68,11 & 45,2 \\
\hline $\begin{array}{l}\text { Строкові } \\
\text { депозити }\end{array}$ & 28,64 & 61,6 & 34,58 & 61,5 & 49,45 & 52,5 & 67,73 & 46,5 & 82,04 & 54,8 \\
\hline $\begin{array}{c}\text { Всього } \\
\text { депозитів }\end{array}$ & 46,48 & 100 & 56,27 & 100 & $\mathbf{9 4 , 2 7}$ & 100 & 145,59 & 100 & 150,15 & 100 \\
\hline
\end{tabular}

*Джерело: складено на основі [3]

інноваціями на банківському ринку є послуги, що впроваджуються із застосуванням дистанційного обслуговування клієнтів, сутність якого полягає у самообслуговуванні клієнта через системи онлайн-банкінгу - Інтернет-банкінгу та мобільного банкінгу, які дозволяють управляти своїми рахунками в режимі «он-лайн» та отримувати широкий спектр фінансової інформації без відвідування банку.

Інтернет-банкінг (веб-банкінг) представляе собою вид дистанційного банківського обслуговування, засобами якого доступ до рахунків та операцій за ними забезпечується у будь-який час та $з$ будь-якого комп'ютера через мережу Інтернет. До послуг Інтернет-банкінгу входять: надання загальної інформації щодо стану рахунків і карток; можливість керування своїми рахунками як в іноземній, так і в національній валюті; оплата комунальних платежів; поповнення рахунків операторів мобільного зв'язку; оплата рахунків за товари; відкриття додаткових карток i рахунків; блокування платіжних карток клієнтом; переказ коштів тощо.

Мобільний банкінг (мобайл-банкінг) — це сервіс для власників банківських карток, який дозволяє управляти рухом коштів на рахунках за допомогою мобільного телефону. До переваг мобільного банкінгу також можна віднести можливість здійснювати грошові перекази; отримувати оперативну інформацію у вигляді SMS-повідомлень про платежі та надходження, про баланс рахунку; останні здійснені платежі тощо [5].

ПАТ «Ощадбанк» одним із перших вітчизняних банків запровадив дистанційне обслуговування клієнтів із застосуванням новітньої банківської послуги «Ощад 24/7». Банк створив новий багатофункціональний, адаптований під мобільні платформи сайт, на якому можна переказувати кошти, сплачувати рахунки, здійснювати різноманітні фінансові операції. Оновлення платформ Інтернет-банкінгу та 
мобільного банкінгу дало можливість Ощадбанку запропонувати клієнтам розширений перелік онлайн-сервісів «Ощад 24/7». За кількістю послуг банк став одним із лідерів інноваційного фінансового ринку України.

Із метою розширення доступності банківських послуг у Ощадбанку за останні два роки відкрито 410 відділень нового типу, серед яких мобільні відділення на базі броньованих автомобілів КрАЗ. У відділеннях створено 260 зон самообслуговування, де встановлено 1590 терміналів і 3405 банкоматів. Розрахунки через термінали Ощадбанку проводять, зокрема, «Нова пошта», патрульна поліція, WOG CAFE у потягах Інтерсіті та багато міжнародних компаній: «МакДональдз», «Ашан», DHL Express Україна, TUI Ukraine, Turkish Airlines та інші. Дистанційним банкінгом «Ощад 24/7» уже користуються 1,8 млн. клієнтів. Вартою уваги $є$ інноваційна програма банку щодо підтримки малого та середнього бізнесу, як пріоритетного напряму надання соціально орієнтованих банківських послуг. Реалізація вказаної програми дозволила у 2017 році збільшити кількість клієнтів на $38 \%$, що призвело до збільшення депозитної бази банку втричі - із 4,7 млрд. грн. до 13,9 млрд. грн. [3].

Одним із важливих напрямів стратегії Ощадбанку $є$ інтеграція в європейський фінансовий простір та підвищення конкурентоспроможності через запровадження у свою діяльність інноваційних банківських послуг європейських країн. У 2016 році у рамках стратегічного партнерства 3 Свропейським банком реконструкції та розвитку (СБРР) відбулося підписання документів, які передбачають комплексну програму трансформації корпоративного управління, операційної та фінансової діяльності банку. Зважаючи на те, що у Стратегії розвитку державних банків передбачена можлива часткова приватизації системних державних банків, СБРР має намір інвестувати кошти в акціонерний капітал Ощадбанку [4].

Висновки і перспективи подальших досліджень. У процесі дослідження 3'ясовано, що головною передумовою успішного довгострокового розвитку банків $є$ наявність та ефективна реалізація системи інноваційного стратегічного менеджменту, важливою складовою якої $\epsilon$ депозитна стратегія, яка забезпечує ефективне проведення депозитної політики щодо цільових ринків та клієнтів, обсягів і структури депозитної бази, а також впровадження інноваційних депозитних послуг та модернізацію продуктового ряду.

Результати аналізу інноваційної стратегії ПАТ «Ощадбанк» на ринку депозитних послуг засвідчили запровадження Ощадбанком програми модернізації банківської мережі, яка включає інноваційну продуктову політику, створення нових банківських продуктів i послуг, розширення бізнес-проектів на підтримку малого та середнього бізнесу. Ощадбанк входить у першу п'ятірку банківських установ України зі впровадження Інтернет-технологій.

Проведене дослідження дозволило дійти висновку, що стабілізація банківської системи України у сучасних умовах потребує від банків розроблення та використання методів економного ведення діяльності, які базуються на швидкому впровадженні новітніх інформаційних технологій та розширенні мережі інноваційних банківських продуктів i послуг. За наявного чинного формування депозитної політики українських банків, навіть 3 урахуванням високого професіоналізму менеджерів, ще залишається значний ступінь банківських ризиків. Тому, на думку експертів, вітчизняна банківська система потребує здійснення таких заходів, як:

- створення достатньої науково-методичної бази, необхідної для розроблення і реалізації депозитної стратегії;

- підготовка науковців та практиків, спроможних впроваджувати новітні технології 3 урахуванням національних особливостей банківського біснесу;

- створення центрів, які зможуть координувати у масштабах держави роботу, пов'язану 3 формуванням ресурсного потенціалу банків;

- забезпечення надійної системи комунікації банків із громадськістю;

- підвищення рівня фінансової грамотності населення, змістовного рівня спеціальних i науково-популярних публікацій тощо.

\section{ПЕРЕЛІК ВИКОРИСТАНИХ ДЖЕРЕЛ}

1. Котелевська Ю. В. Сучасні підходи до формування маркетингової стратегії розвитку банківської системи України в умовах глобалізації та євроінтеграції / Ю. В. Котелевська, Т. В. Новікова // Вісник УБС НБУ. 2013. - № 2. - С. 152-156.

2. Марич М. Г. Інноваційні стратегії розвитку банків / М. Г. Марич // Вісник Одеського національного університету. Серія: Економіка. - 2016. - Т. 21. - Вип. 5. - С. 182-186.

3. Офіційний сайт ПАТ «Державний ощадний банк України» [Електронний ресурс]. - Режим доступу: http://www. oschadbank.ua. 
4. Стратегія розвитку державних банків [Електронний ресурс]. - Режим доступу: http://www.minfin.gov.ua.

5. Чиж Н. М. Банківські інновації: проблеми та перспективи / Н. М. Чиж, М. І. Дзямулич // Економічні науки. Серія: Облік і фінанси. - Випуск 9 (4). - 2012. - С. 403-411.

\section{REFERENCES}

1. Kotelevs'ka, Yu. V. (2013). Suchasni pidkhody do formuvannya marketynhovoyi stratehiyi rozvytku bankivs'koyi systemy Ukrayiny v umovakh hlobalizatsiyi ta yevrointehratsiyi [Modern approaches to the formation of a marketing strategy for the development of the banking system of Ukraine in the conditions of globalization and European integration]. Visnyk UBS NBU - Bulletin of the UB NBU, 2, 152-156, [in Ukrainian].

2. Marych, M. H. (2016). Innovatsiyni stratehiyi rozvytku bankiv [Innovative bank development strategies]. Visnyk Odes'koho natsional'noho universytetu. Seriya: Ekonomika - Bulletin of the Odessa National University. Series: Economics, 5, 182-186, [in Ukrainian].

3. Ofitsiynyy sayt PAT « Derzhavnyy oshchadnyy bank Ukrayiny» [Official site of PJSC «State Savings Bank of Ukraine»]. www.oschadbank.ua. Retrieved from: http://www. oschadbank.ua [in Ukrainian].

4. Stratehiya rozvytku derzhavnykh bankiv [Strategy of state banks development]. www.minfin.gov.ua. Retrieved from: http://www.minfin.gov.ua [in Ukrainian].

5. Chyzh N. M. (2012). Bankivs'ki innovatsiyi: problemy ta perspektyvy [Banking innovations: problems and prospects]. Ekonomichni nauky. Seriya: Oblik i finansy - Economic sciences. Series: Accounting and Finance, 9 (4), 403-411 [in Ukrainian].

Одержано 13.09.2018 p. 